\title{
Effect of Water Quality Values on Gammaridae and Ephemeroptera Biodiversity in Mezit River (Bilecik-Turkey)
}

\author{
Sıdıka Aksoy, Nesil Ertorun, M. Burçin Mutlu \\ Anadolu University, Faculty of Science, Biology Department \\ Eskişehir, Turkey \\ Sidikaaksoy@Anadolu.Edu.Tr; Nesile@Anadolu.Edu.Tr; Mbmutlu@Anadolu.Edu.Tr
}

\section{Extended Abstract}

The aquatic environment can be defined as the interaction system of water and aquatic life. Along with the rapid proliferation of human and animal populations on the world, more water resources are needed and the rate of degradation of aquatic environments is further increased. The quality of the water environment and the properties affecting the dynamics of this environment are affected by increased pollution [1]. Therefore, the preservation of these resources and the work done in this area have great precaution. In determining the quality of an aquatic environment, the physical and chemical parameters are used together to determine the water quality class. Studies of water quality are not only related to water, but also to all living organisms in which water is a living environment [2]. Quality class has an effective role in determining which living taxa can or cannot live. It is a fundamental issue that concerns biological diversity in the water along with changes in water parameters and how the biomass undergoes a change. Thus, ecological and zoological assessments can be made by determining the correlation between water quality and living diversity. When previous studies were examined, it was determined that no such research was conducted in Mezitler (Bozüyük-Bilecik-Turkey) region. Other parameters (COD and ammonium) were measured in the laboratory environment while the physicochemical parameters $(\mathrm{pH}$, temperature, redox, DO and EC) of the water samples were measured in field studies in Mezitler region. At the same time, the most dominant taxa in the study area were found to be members of Gammaridae (Gammarus balcanicus, Gammarus agrarius) and Ephemeroptera (Baetis rhodani, Electrogena lateralis, Ephemerella ignita) [3-4]. In this study, Gammaridae members who used to measure stress conditions and Ephemeroptera nymphs which used water quality studies were evaluated as bioindicators for the quality evaluation of different stations [5-6]. Water samples were taken from the river and $\mathrm{pH}$, temperature values and chemical oxygen demand (COD) values of the samples were determined. COD values ranged from 10 to $48 \mathrm{mg} / \mathrm{L}$, temperature values ranged from 5 to $20{ }^{\circ} \mathrm{C}$ and $\mathrm{pH}$ values ranged from 7.0 to 8.3. It is observed that the water quality changes when these values are examined [7]. According to the data obtained from different field studies, species numbers of Gammaridae and Ephemeroptera respectively changes between 250-390 and 28-35 values, that depending on COD and temperature. Physicochemical parameters, COD, ammonium and hydromorphological analysis, results of water samples were interpreted by SPSS program. ANOVA statistical analysis indicated significant statistical differences between COD and number of species $(p<0.05)$, indicated significant statistical differences between temperature and number of species $(\mathrm{p}<0.05)$, but no significant differences number of species were not significantly affected by $\mathrm{pH}$ levels ( $\mathrm{p}>0.05)$ in the studies. As a result of this study, the relation between water pollution and biological and chemical data of Gammaridae and Ephemeroptera species was determined. Water quality values were found to be effective in the biodiversity and variety of Gammaridae and Ephemeroptera species.

\section{References}

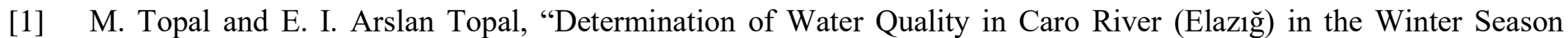
2014-2015 in Terms of Some Physicochemical Parameters," Bitlis Eren University Journal of Science, vol. 4, no. 1, pp. 43-53, 2015.

[2] D. Walker et al., "Multi-criterion water quality analysis of the Danube River in Serbia: A visualisation approach," Water Research, vol. 79, pp. 158-172, 2015. 
[3] G. S. Karaman and S. Pinkster, "Freshwater Gammarus species from Europe, North Africa and adjacent regions of Asia (Crustacea-Amphipoda). Part III. Gammarus balcanicus-group and related species," Bijdragen tot de Dierkunde vol. 57, no. 2, pp. 207-260, 1987.

[4] B. Eiseier, "Identification key to the mayfly larvae od the German Highlands und Lowlands," International Zeitschrift für Faunistik und Floristik der Bnengewasser Europas, Lauterbornia, Dinkelscherben, no. 53, pp. 1-112, 2005.

[5] M. Graça, A. Rodrigues Capitulo, C. Ocón, N. Gómez, "In situ tests for water quality assessment a case study in Pampean rivers," Water Research, vol. 36, no. 16, pp. 4033-4040, 2002.

[6] N. Kazancı and G. Türkmen, "Habitat Characteristics of Ephemeroptera (Insecta) Species in a Preservation Area and Use of Protected Area Limits as an Indicator in Determination," E.U. Journal of Fisheries \& Aquatic Sciences, vol. 24, no. 4, pp. 325-331, 2008.

[7] S. S. Mahapatra et al, "A Cascaded Fuzzy Inference System for Indian River Water Quality Prediction," Advances in Engineering Software, vol. 42, pp. 787-796, 2011. 